\title{
PLANNING LAW AND DEMOCRATIC LIVING
}

\author{
Norman WiLLIams, JR.*
}

I

The Legal and Social Framework of Planning

A. The Scope of Planning

This symposium explores various problems arising out of the integration of planning with that system of social control known as law, with special emphasis on problems of constitutional law. As used here, "planning" means the process of consciously exercising rational control over the development of the physical environment, and of certain aspects of the social environment, in the light of a common scheme of values, goals, and assumptions. Planning is concerned with guiding both public and private action, and may be on a local, metropolitan, or regional basis.

In planning, primary emphasis is on the physical environment; yet the social environment is also involved in many ways. First, intelligent correlation of decisions on the development of the physical environment necessarily involves having consistent assumptions and policies derived from the social environment, as for example on the size and characteristics of the population, even though such matters are left generally to individual decisions. Second, in some instances attempts are made to influence individual decisions on such matters, as for example population migration and the birth rate-although here there is a wide difference of opinion on how far planning should go. ${ }^{1}$ Finally, the distinction between the physical and the social environment is really an artificial and untenable one anyway, since the arrangement of the physical environment has a decided impact upon social conditions, and vice versa.

This process of conscious and purposeful control over the development of the physical and social environment in a relatively free society is something rather new in history. Moreover, in such a society the development of techniques to forecast probable future trends, and thus to ascertain and evaluate the range of possibilities within which control may be exercised, is a difficult process at best. The development of effective methods of exercising such control is even more difficult. Any consideration of planning techniques must therefore start with a realization that planning for the future environment is still in the experimental stage, and that the techniques available, while extremely useful, are still rather crude. It is a truism to

\footnotetext{
- Member of the New York bar; Director, Division of Planning, Department of City Planning, New York City.

${ }^{2}$ The one point on which there is universal agreement is that the precise outer limits of urban and regional planning are not easy to define. However, we are not concerned here with over-all cconomic planning in the socialist or collectivist sense.
} 
say that even the best plans must be subject to constant review in the light of changing conditions. Moreover, what techniques are available have generally not been thought out in terms of all their implications for the whole environment. There is therefore no reason to be surprised if this symposium raises more questions than it answers.

\section{B. Planning and Constitutional Law}

The main premises of American constitutional law represent a codification and institutionalization of the primary values of a democratic society-equality of opportunity and equality of treatment, freedom of thought and considerable freedom of action, and fairness. Under the American system, a more or less independent mechanism of judicial review is established to provide an independent check on whether specific governmental decisions conform to these standards. While controversy has often raged about judicial action in other areas, it has always been recognized that it is an essential part of the judicial function to watch over the parochial and exclusionist attitudes and policies of local governments, and to see to it that these do not run counter to national policy and the general welfare.

Constitutional law should serve to shed light upon thinking about local planning, by requiring those concerned to do what they should be doing anyway-to work out the relationship between planning the future environment and the great issues connected with human freedom and opportunity. However, instead of fulfilling this high mission, the role of constitutional law in the field of planning has generally been in part to obstruct effective action, and perhaps even more to stultify thinking on these problems by confusing them with meaningless abstraction and legal fiction.

In order to get planning decisions and regulations upheld by the courts, which are usually unknowledgeable about the problems involved and often tend to be hostile, primary emphasis in planning litigation has, naturally enough, usually been placed on whatever arguments seem likely to make the particular regulations involved easiest to uphold. Thus, in zoning cases, no matter what the real problems are, it is generally argued that the regulations under attack were really concerned with considerations of public health and safety. ${ }^{2}$ Moreover, it is customary also to invoke "the general welfare," in a way which seems to assume that this is something definite and meaningful, and also something quite different from health and safety. It is rare that the particular problems affecting health, safety, or other aspects of welfare are spelled out, analyzed, and evaluated. There is then no reason to be surprised that the resulting court opinions tend to proceed on a remarkably low intellectual level. ${ }^{3}$ While the leading constitutional thinkers have been largely

\footnotetext{
${ }^{2}$ Perbaps the classic example is the argument that restrictions on billboards, far from bcing an aesthetic matter, are really concerned with protecting public safety and morals-because, after all, billboards might blow over and land on somebody, and because all sorts of nasty things might go on bchind them. See Cusack Co. v. City of Chicago, 267 Ill. 344, I08 N.E. 340 (1915), affd, 242 U.S. 526 (Igr7). Legal fiction can hardly hope to progress beyond this.

${ }^{3}$ It should be remembered that zoning cases, which make up by far the largest part of planning
} 
ignoring this whole area of law, small-time constitutional lawyers have thus been making their own distinctive (and rather substantial) contribution to the general muddle which surrounds thinking about planning matters.

Yet in planning for the whole future environment, many decisions may involve great and often difficult constitutional problems. For those issues and values which are fundamental in deciding what sort of a future environment is desirable, are often the very same issues and values which are most relevant in applying the great constitutional guarantees of fairness, equality, and liberty of action. There are infinite examples; a few will illustrate the point. If we are really serious in our desire for maximum freedom of individual action and equal opportunity for everyone, what implications does this have for planning future schools and the future supply of housing? In a society characterized both by genuine democratic trends and by wide areas of discrimination, prejudice, and snobbery, what is the meaning of equal treatment in providing facilities for people in such obviously unequal circumstances? ${ }^{4}$ Or, if a policy of eliminating (or discouraging) non-conforming uses is applied vigorously in new residential areas, but cannot "practically" be enforced in slum residential areas which are full of mixed uses, how can this be squared with the concept of equal protection of rich and poor from noise, air pollution, and traffic dangers? Or, to put the matter broadly, what is involved in creating an environment suitable for democratic living?

An intelligent application of constitutional law to the measures used in planning the environment will therefore force a searching inquiry into basic problems-and thus become in fact an excellent vehicle for getting at what is really involved in planning decisions. If such searching inquiries are to be undertaken, this means that no major problem in planning law can really be understood except by an analysis thereof in relation to the whole background of the changing physical, economic and social environment. In short, what is needed in planning law is a superBrandeis-brief approach.

\section{Planning and Conflicting Social Forces}

The way cities develop, it is not the case that a thorough planning analysis will always reveal a single solution which will best satisfy the needs of everyone involved. In fact, one is sometimes tempted to say that such situations are rare. In many, if not most, instances, there are likely to be opposing forces at work. These opposing forces may involve quite different desires or implications for the future environment; or the problem may be one of distributing insufficient public services to the areas of greatest need. It is remarkable how often, in a highly technical planning dis-

litigation, are usually handled by small-time lawyers for a small-time fee, and therefore in a hurry. Many opinions read as if (as was probably the case) the lawyers considered their job done when they had found the leading zoning case in their own jurisdiction, and then copied out long passages of vague language about property rights, due process, the police power, and public health, safety and general welfare-which then end up as the first few pages of the court's opinion.

'See Judge Edgerton, dissenting in Hurd v. Hodge, I62 F.2d 233, 235 (D.C. Cir. 1947), reversed, 334 U.S. 24 ( 1948 ), as quoted on p. 337 infra. 
cussion, differing uses of various planning devices can be most realistically viewed as rather sophisticated expressions of different social forces-between which a balance must be struck, or a decision made. The fact that these conflicting social forces may not be immediately apparent in connection with planning decisions, or that only one side may be vocal or vociferous, does not mean that the conflicts are not there. Nothing is more important than to be clear-headed about this. When one of these situations arises, normally there is no such thing as avoiding the issue, or making a decision on the "technical" and "non-controversial" problems only, or finding a safe and dignified refuge in accumulating endless piles of unassimilated information and hoping that somehow it will speak for itself. In brief, in these situations there is no such thing as neutrality. There is, however, plenty of opportunity for being so muddle-headed as not to realize what is going on, and what issues are actually being decided.

Again, plenty of examples are available; a few will suffice. Take the question of locating a hospital in a low-density residential area. Nearby residents will frequently object, because of the probability of increased vehicular traffic, more cars parked in the streets, disturbance of a quiet environment, etc.; and so zoning regulations frequently exclude hospitals from such areas. On the other hand, a relatively quiet residential environment, preferably with a bit of greenery, is recognized as an integral part of modern medical care; and so, if all future hospitals are forced into more crowded and less desirable environments, the sick are likely to suffer. ${ }^{\mathscr{b}}$ Or, similarly, a number of forces and devices are often at work to exclude various minority groups-frequently rapidly growing minorities-from living in certain areas; and all sorts of arguments are adduced in support of such a policy. Such exclusion, if widespread and effective, automatically becomes a major factor in preventing a sufficient supply of decent housing for such minorities-resulting directly and increasingly in overcrowding, and also contributing indirectly to various forms of social disorganization-which is then blamed on almost everything except the policy of exclusion. Or, again, school districts near the boundary between a white and a non-white residential area may be arranged so as largely to segregate the races into different schools, frequently with the result that the white schools will be underutilized and the Negro schools overcrowded. If another school is built in the Negro area to relieve the overcrowded school there, this may involve an implicit acceptance of the permanence of the segregated pattern; if one is not built, it is the Negro pupils who are likely to continue to suffer. This last is one of many situations where there is not only no possible neutrality, but no solution which is morally tolerable from a democratic standpoint.

To state the problem more generally, there is perhaps an innate conflict in the whole business of local and regional planning. Inevitably, the logic of any pro-

\footnotetext{
'Now that population growth is occurring largely in the lower-density suburban areas, this problem may become more serious. The best solution is to permit hospitals in such areas, subject to severe rcstrictions for required open space around buildings, required off street parking spaces, and screcning.
} 
cedure which seeks to analyze all needs impartially, and to provide for these in order of priority, has a built-in democratic bias. Yet, particularly since planning is so largely administered locally, there is no question that planning techniques (and technicians) have often been utilized for local and exclusionist purposes-even though in effect this obstructs planning for the larger areas.

Since many of the problems reviewed below will involve just such conflicting social trends, the premises assumed herein had better be explicitly stated. While the reality of other social attitudes is recognized, this article will proceed upon the same assumptions as does the Constitution, and in fact so much of American history and experience-“"The American Creed," i.e., the belief in equal opportunity and equal treatment. ${ }^{6}$ Moreover, it will be assumed that, to the extent that frictions arise from cultural differences, appropriate conditions are present so that either (a) assimilation will eliminate or reduce those differences, or (b) education will result in acceptance of such differences. This article will be concerned primarily with those problems of planning law which are of the greatest significance in democratic development.

\section{II}

\section{The Significance of a Changing Environment}

A. The Influence of the Environment on the Possibilities for Democratic Living Among the more significant conflicts relating to the environment are those conflicts which revolve around the creation of an environment favorable or unfavorable to the creation of democratic patterns of living. Moreover, it appears likely that the arrangement of the environment is one of the major factors in the development of democratic living patterns.

While not much scientific evidence exists about the effect of the environment on living patterns, a few recent pioneering studies are certainly suggestive. A successful democratic system presupposes wide areas of mutual friendship and/or respect; and a basic question is-what are the conditions under which such relationships are likely to arise? Apparently the arrangement of the environment has considerable significance in this respect. For example, in a study of a medium-size NorthEastern city, most marriages were found to have occurred between parties living relatively near each other: about 75 per cent came from people living within 20 blocks of each other, and 35 per cent actually came from within 5 blocks. $^{7}$ An analysis of how friendships arose in two adjoining temporary veterans' housing projects under university auspices (one row-house and one apartment-building) also emphasized the remarkable importance, in this special situation, of two factors in friendshipformation-first of distance, including even very small distances, and second of physical design, particularly the orientation of houses and the location of stairways. ${ }^{8}$

\footnotetext{
- See Gunnar Myrdal, An American Diremama lvi, 23-25 (1944).

7 Abrams, Residential Propinquity as a Factor in Marriage Selection, 8 AM. Soc. Rev. 288 (I943) (in New Haven).

${ }^{8}$ Leon Festinger, Stanley Schachter and Kurt Back, Social Pressures in Informal Groups
} 
Most friendships in this project developed either within the same court or within the same floor in a larger building, and a large proportion occurred between families living only a few feet apart. Moreover, those few families who lived in houses facing away from their courts fared noticeably worse, while in the larger buildings those living near the stairways fared noticeably better.

Similarly, a study of different patterns of inter-racial public housing in otherwise quite similar projects located in two neighboring large North-Eastern cities also brought out the importance of proximity in developing friendly relationships. ${ }^{0}$ In one city, where the projects had completely integrated inter-racial occupancy, the result was a striking degree of mutual friendliness within the projects. In a nearby city, whites and Negroes were segregated into different parts of each project, and the result was a good deal of distrust and lack of knowledge. In these cases the influence of the occupancy pattern actually overcame and dominated attitudes derived from varying religious, political and educational backgrounds.

The influence of environment upon living patterns has also been documented in other areas. Almost everyone is now familiar with the considerable relationship between bad housing conditions and tuberculosis, crime, juvenile delinquency, etc. A study of the distribution of mental disease in a metropolis indicated that most (though not all) types of psychosis arose primarily in certain areas, particularly the central roominghouse areas, which had a peculiar kind of social organization and physical facilities available therefor. ${ }^{10}$ In his classic description of Southern interracial etiquette, Myrdal noted an entertaining little point-that a new architectural trend, the development of houses built without any back door, was necessarily beginning to undermine one feature of that caste etiquette, the requirement that Negroes always go to the back door of houses occupied by whites. ${ }^{11}$ All these instances merely underline the rather obvious point that the facilities available for living have considerable effect upon how people live.

Assuming that democracy requires a substantial degree of mutual respect, the point suggested by these findings may be stated more generally. The development of such mutual respect between various groups is dependent in considerable degree upon some opportunity for regular human contacts, preferably in a relationship which implies equality rather than difference in status. Moreover, the importance of living near members of other groups is specifically emphasized. However, the needs

(x950). The projects were at M.I.T. The most remarkable thing about this pattern is that it developed among a homogeneous group where the husbands had other regular contacts, in the classroom. Yet the temporary nature of the occupancy may have had other influences on the pattern.

${ }^{\circ}$ Morton Deutsch and Mary E. Coleins, Interracial Housing (I95I). The two cities were New York and Newark. The immediate result of this study was that the Newark Housing Authority adopted the same fully integrated renting pattern as New York.

${ }^{10}$ R.E.L. Faris and H. W. Dunham, Mental Disorders in Urban Areas (i939) (on Chicago). The exceptions were manic-depressive psychosis and catatonic schizophrenia. One striking fact, which might indicate a special limitation on the general thesis of this article in certain types of areas, is that members of ethnic groups living in areas which were populated largely by other ethnic groups, generally had high rates of schizophrenia and alcoholic psychosis.

${ }^{11}$ MYrdal, op. cit. supra note 6, at 613. 
of the situation vary as American society changes. In the "good old days" of smalltown America, inter-group contacts were more or less automatic; residential segregation by income group was either limited or more or less non-existent, and everybody saw everybody else "down-street" regularly anyway. A considerable number of people still live in such communities, but the great majority no longer do. The growth of big cities brought a great increase in residential and social segregation by classes and by ethnic groups, often sharply divided even when physically adjacent (in "Dead End" fashion). The big question is whether, and how, such contacts are to arise in the situation which is developing from current trends in urban and suburban migration and development.

\section{B. Current Changes in the Physical Environment}

If it is true that the physical environment has a substantial effect upon living patterns and thus upon democratic development, then it is appropriate to review briefly current changes in that environment, before turning to an analysis of various devices to regulate the development thereof.

I. Residential. Large-scale changes are taking place in connection with the development of new residential areas. First, the scale of development of land for residential purposes has changed. Before the last war, most residential construction was done by small operators erecting a few houses apiece; but now a very sizable proportion of new housing-up to nearly half the total in some cities-is developed in large projects, each ranging from a few blocks to the equivalent of a large city. ${ }^{12}$ Second, new building forms are emerging, particularly among the big projectsgarden apartments, tall apartment buildings set in open land apart from streets, ranch houses, etc.; and each of these is likely to involve new living patterns. A major change here is the freeing of residential site planning by breaking away from the traditional gridiron street pattern. Third, various new density patterns are emerging, as more open space tends to appear around all kinds of residential buildings, and as buildings get taller. A generation or two ago, apartments were synonymous with huge bulky buildings with high coverage, ${ }^{13}$ and even single-family detached houses were often crowded so close together that neighbors could shake hands across from house to house. However, new apartment developments now often have a density lower than that of two-family houses, and sometimes comparable to single-family houses. For single-family detached houses the 30 -foot lot has become an anachronism, and lots between $5^{\circ}$ and roo feet in width are common, even apart from luxury housing. On the other hand, the taller new apartment build-

\footnotetext{
${ }^{12}$ For example, Stuyvesant Town in New York City would, if a separate city, be about the 25th largest city in that state; and the second Levittown, in Bucks County, Pennyslvania, would (when completed) be about the roth largest city in that state. And yet, since these qualify generally as private developments, they are not generally subject to the sanctions applicable against state action in many communities which are only a small fraction of their size. See discussion on pp. 341-343 and note 79 infra. Compare Marsh v. Alabama, 326 U.S. 50r (I946).

${ }_{13}$ The general attitude of the times towards bulky apartments invading low-density residential areas is reflected in such decisions as Wulfsohn v. Burden, 241 N.Y. 288, 150 N.E. I20 (I925), and Pritz v. Messer, II2 Ohio St. 628, I49 N.E. 30 (I925).
} 
ings, even when set in open land, often represent an increase in density. In general, while the new developments represent great gains in physical amenities, their effect upon neighborliness is at least questionable.

2. Non-Residential. Commercial and industrial development is also undergoing considerable change. Within a few decades, the focus of shopping activity in this country has shifted from the old-time village store, first to the city department store and speciality shop, and now increasingly from the latter to the outlying suburban shopping center-usually centering around a super-market, several chain stores, and perhaps a branch department store, and surrounded by huge areas for parking. Obviously each of these forms results in quite different patterns of human contacts. In a similar (or shorter) period, the main emphasis in recreation has shifted, first from the home (parlor games and visiting on the front porch) to activities outside the home (the automobile, movies, country clubs, and amusement parks), and now partly back towards the home with the development of television. Here there has been increased variety of opportunity, some genuine cultural development, much sleazy commercialism, and perhaps some net loss in the opportunities for human contacts.

Industrial development is also changing considerably. For example, the shift of the power base toward electricity has opened the way for more decentralization of industry; and new manufacturing plants, set in big lawns, often look more like community centers than like the traditional factory building, dark and dreary and usually belching smoke.

3. Transportation. Underlying many of these, and perhaps most important of all, the new developments in transportation have made their influence felt everywhere. As a result of the growth of automotive traffic, the old urban street systems have been overwhelmed, so that both traffic movement and off-street parking ${ }^{14}$ have become major urban headaches; new residential development has sprawled out away from employment areas, and has filled in the areas between the radial pattern of transit lines; and industry has been similarly freed from dependence upon facilities for rail and water transport. The great increase in travel-to-work by automobile, heavily subsidized by huge public expenditures on highways, has led to the controversy on "rails v. rubber"-i.e., whether public policy and investment should encourage mass rapid transit along with (or instead of) more automotive traffic, and especially individual cars, as the best means of bringing large numbers of people into metropolitan centers without cluttering their overcrowded streets with even more cars. Meanwhile air transport has brought the whole country within the

\footnotetext{
14 Increasing traffic has brought about a complete reversal in the attitude towards off-street parking facilities in the last forty years. In the early zoning ordinances, garages were often prohibited in general commercial districts-partly because garages then were often converted stables, and the aroma tended to linger on. Recently accessory off-street parking spaces (which, despite certain important differences from commercial garages, are still basically the same type of facility) have been widely not only permitted but required, in commercial and even in residential districts.
} 
compass of a few hours' trip, and created new urban problems, with noise and danger tending to blight huge areas around the airports. ${ }^{15}$

C. Current Changes in the Social Environment

Even more than changes in the types of new buildings, changing trends in occupancy of buildings-particularly residential buildings ${ }^{16}$ - have significant effects upon the development of democratic living patterns. For now, as during most of American history, large numbers of people are moving around the country, and as a result great changes are occurring in the distribution of ethnic, racial, economic, and age groups in residential areas.

I. Migration. The remarkable amount of current movement all over the country is bringing about the rapid development of new areas, great changes in the occupancy of older areas, and new demands for public services everywhere. Several major trends are evident. In the first place, the long-term movement from countryside and small town to the big cities is changing from a general nation-wide pattern to a heavy concentration in two special types of movement. First, migration is continuing from East and Midwest to the rapidly growing metropolitan areas in the West and the Southwest, for climatic or economic reasons; the Iowans in Los Angeles are a famous example. ${ }^{17}$ Also, there has been a great increase in the migration of Negroes from Southern rural areas to both Southern and Northern big cities, in order to improve their economic and their cultural position; and certain areas have also experienced large-scale in-migration of Puerto Ricans or Mexicans. In the second place, the movement of upper- and middle-income whites from the big cities out into new lowdensity areas, usually suburban areas with separate local governments, is approaching flood proportions. The resulting changes in the development and occupancy of residential areas constitute the background for many of the most important recent constitutional problems related to planning the future environment. For example, what may turn up in zoning as a building-type or density regulation may in fact be an expression of the conflict between different groups over occupancy of some residential area.

2. Homogeneous or Heterogeneous Residential Areas. One of the major factors in the occupancy of residential areas or communities is whether they are homogeneous or heterogeneous, particularly with respect to four major types of characteristics-ethnic, racial, economic, and age. This aspect of the environment has particular significance with respect to the promotion of democratic values, especially because of the current trends in migration mentioned above.

\footnotetext{
${ }^{15}$ An analogous phenomenon, and one which causes a very large part of the friction in zoning, is the problem of what to do with the extensive frontage along heavily-travelled streets. Usually there is insufficient demand for business to use more than a part of it; and yet such frontage is likely to be both none too pleasant for residential use, and rather unsafe at least for families with small children.

${ }^{10}$ While the rest of this article will be concerned with occupancy of residences, there are important problems which arise in connection with employment, shopping, recreation, etc., which also deserve detailed consideration.

${ }^{17}$ Carey McWilliams, Southern California Country y67 ff. (1946).
} 
In addition to its primary significance in connection with the possibility of developing friendly human contacts and mutual respect between groups living near each other, the question of homogeneity or heterogeneity in residential areas has other major indirect consequences. First, schools and many other public facilities normally serve the residential areas nearby, and so residential segregation provides the foundation for segregation in these other facilities. Even where communities are proceeding with the best faith in the world to abolish segregation in the schools, in accordance with the recent Supreme Court decision, ${ }^{18}$ most children belonging to minority groups are likely to continue in segregated schools as long as the residential areas from which they come remain segregated. Second, in the frequent case of rapidly-growing minority groups, the restricted space available for their housing in segregated areas results in acute overcrowding of available residences; and this overcrowding in turn results in various social tensions and cultural strains-the existence of which is then used as an argument against expansion of the crowded areas! Moreover, there is another not inconsiderable point. So long as these minority groups remain boxed up in inadequate and overcrowded areas, there will be special difficulties in the way of small-scale experiments in developing integrated residential areas. For when an area begins to open up to members of some minority, there is often an interim period of unstable occupancy; and during this period, unless the situation is handled skillfully and with restraint, the acute pressure for more minority housing may result either in open violence, or in a complete overturn in occupancy-i.e., not in integration but merely in an expansion of the segregated areas.

It should be frankly recognized that the basic question here is one of two conflicting sets of moral values, both of which exert a powerful influence on the American mind. On one side is "The American Creed" of equality and equal treatment for all. On the other is the preference for those who are culturally similar, combined with the desire to maintain status-"keeping up with the Joneses."

3. Ethnic. American history is rich in experience in handling ethnic conflicts, deriving from the gradual but continuous partial amalgamation of national, religious and other ethnic groups. ${ }^{19}$ This is the famous "melting pot," a major theme in American history from the conflicting seventeenth century ethnic frontiers of settlements from different European countries to the current cultural strains sometimes associated with the movement of various minority groups (Jewish, Italian, Polish, etc.) into residential areas. The speed and ease of assimilation are likely to depend upon the extent of the economic and cultural differences involved. Immigrants from Great Britain and France have generally been assimilated rapidly, and the same has often been true of the Germans, because their economic and cultural status

\footnotetext{
${ }^{18}$ Brown v. Board of Education of Topeka, 347 U.S. 483 (1954).

${ }^{10}$ Prejudices against ethnic and racial groups regularly affect the lives of at least one-sixth of the population, of which the great majority are Negroes, Jews, and Mexicans. In addition, there are other groups which are affected in certain localities, but not universally. See Williams, Discrimination and Segregation in Minority Housing, 9 AM. J. Econ. AND Soc. 85 ( $\times 949$ ).
} 
has resembled that of the rest of the population. On the other hand, after their arrival en masse in the mid-nineteenth century, the Irish, ${ }^{20}$ and in some areas the Scandinavians, were culturally more different, economically more impoverished, created more difficult conflicts, and took longer to assimilate. The mass immigration of Italians and various Eastern European groups, particularly around the turn of this century, resulted in a similar pattern. The degree of cultural difference between each ethnic group and the rest of the population, and so the degree of resistance to that group's movement into residential areas, now depends primarily upon how long that group has been in this country. The essential point is that all over the country, there are all sorts of ethnic groups at all different stages in the process of assimilation.

Among the many problems created during assimilation, ${ }^{21}$ we are concerned here with the segregation of ethnic groups in residential areas, and their gradual residential de-segregation. For each successive immigrant group which started with substantial cultural differences, the residential pattern has normally gone through a series of successive stages. At first such immigrants voluntarily gather in homogeneous areas, sometimes not dissimilar from the compulsory European ghetto, because of common language, customs, and educational and religious institutions, and perhaps similar employment opportunities. Most big cities have had or still have examples: the Irish in the North End of Boston, the Jews in the Lower East Side of New York, and the Italian areas in New Haven are familiar instances. ${ }^{22}$ However, the pressures toward assimilation begin at once, particularly for the younger generation, through the public schools, the organs of mass communication, the desire for greater social prestige, and to some extent the necessities on the job. The next step is frequently a mass movement of the immigrant group, perhaps stimulated by social pressure from their children, into better housing, either by expansion nearby ${ }^{23}$ or by a jump into an area further out; the Jewish shifts into the Bronx in New York and Lawndale in Chicago are examples of the latter. ${ }^{24}$ Later, the final step is likely to be the gradual scattering of largely assimilated individuals into areas inhabited by the population as a whole. ${ }^{25}$

4. Racial. Racial differences may be described as ethnic differences plus a difference in skin pigmentation; and the major significance of "race"26 in American society

${ }^{20}$ See generally Oscar Handin, Boston's Immigrants I790-I865 (I94I).

${ }^{21}$ While assimilation tends to reduce inter-cultural tension and generally facilitates democratic development, it of course also tends to destroy some of the color and vitality of a diverse group of cultures.

${ }^{23}$ See, for example, HANDLin, op. cit. supra note 20, at 99 ff.; Lours WIRTH, THE GHETTo I95 ff. (I928); Irvin L. Child, Italian or American? 45 ff. (I943).

${ }^{23}$ See W. Lloyd Warner and Leo Srole, The Social Systems of American Ethnic Groups, c 3. passim (1945) (Newburyport, Mass.). According to this study, the successive assimilation or desegregation of various ethnic groups into residential areas lagged behind their rise in occupational status, but preceded their full social acceptance.

a' See WIRTr, op. cit. supra note 22, at $24 \mathrm{I}$ ff.

${ }^{25}$ See Warner AND SRole, op. cit. supra note 23 , c. 3 passim.

${ }^{20}$ The distinction between racial and other ethnic differences is clear-cut on Negroes, Chinese, and Japanese, and most of the small number of other Asiatics, but somewhat muddied on American Indians, Mexicans, and Puerto Ricans. 
is particularly striking in connection with residential patterns. The essence of this American imperfect caste system, a survival of slavery in modified form which has been generalized to apply to other groups, is a direct contradiction of the democratic ideal-a concept of hereditary inferior status, with the premise that assimilation (particularly by inter-marriage) is to be prevented. ${ }^{27}$ This system survives partly by an extraordinary mechanism of self-reinforcement, which operates in a vicious circle. A great premium is placed, particularly in the South where most Negroes still live or have been brought up, upon constant and overt exhibitions of subservience; and in such areas any apparent indications of ambition or worldly success are often frowned upon and penalized as being "uppity." Moreover, educational and recreational facilities are kept to a minimum, often quite consciously. Then any evidence that can be found of lack of ambition, ignorance, and crime is cited as justification for the repressive system. As indicated above, this general vicious-circle mechanism is substantially repeated in connection with housing: as a result of racial segregation, Negroes and other minorities are generally crowded into slums and shacks, urban and rural; and then the living habits which sometimes do result from such surroundings are used as arguments against expansion of the area available. The normal processes of cultural assimilation have thus been severely hampered in their operation with respect to Negroes, and also other "racial" minorities.

The most extreme American examples of residential segregation on a racial basis have been the Indian reservations and the compulsory internment of JapaneseAmericans, including American citizens, in concentration camps for several years during the Second World War. ${ }^{28}$ However, the residential concentration of American Negroes is the most important and the most typical problem.

Patterns of Negro residential settlement vary. In the older Southern cities, particularly Charleston, Negroes live scattered all over the city, though usually so situated to emphasize the difference in status. In Southern rural areas, mixed occupancy is also frequent, but again physical differentiation is usually all too evident, to indicate a status differentiation. On the other hand, in the small Southern towns, there is usually almost complete segregation, often in clusters of shacks at the edge of town. These are the conditions under which most American Negroes either grew up or still live.

In the North the situation has always been different. During the last century Northern urban Negroes generally lived intermingled with other lower-income groups, and were at most only semi-segregated. ${ }^{29}$ However, the twentieth century

${ }^{27}$ See MYrdaI, op. cit. supra note 6, especially at 53 ff., $589 \mathrm{ff}$.

${ }^{28}$ See Comment, Alien Enemies and Japanese-Americans: A Problem of Wartime Controls, 5I Yate L. J. 1316 (1942); Hirabayashi v. United States, 320 U.S. 8x (1943); Korematsu v. United States, 323 U.S. 214 (1944); Ex parte Endo, 323 U.S. 283 (1944); Rostow, The Japanese American Cases-A Disaster, 54 YALE L. J. 489 (1945).

${ }^{29}$ For example, in early I9th century Boston, Negroes had a higher status (and inter-married more with the general population) than the newly immigrant Irish; and about one-half of the Negroes in Boston lived scattered all around town. Handin, op. cit. supra note 20, at 75-76, 100-103, 182 . Sce 
mass migration of Southern rural Negroes has brought great changes for all Negroes living in Northern cities. The predominant pattern in this century has been one of increasing concentration, with the creation-for the first time-of the "Black Belts," areas with almost roo per cent Negro occupancy. ${ }^{30}$ The same pattern has been apparent in those Southern cities whose major growth is recent. Most housing in these areas is deteriorated, overcrowded, and very expensive-with all the usual effects of bad housing. Moreover, in such a ghetto pattern the relatively small but significant Negro upper-class, which provides so much of Negro leadership, is deprived of some of the primary rewards which normally result from an increased living standard in a free society. The anti-democratic implications of these trends are obvious and ominous.

However, there are now signs of a change in these trends, at least in the North. Since this large in-migration of lower-income Negroes (and also Puerto Ricans and/or Mexicans in some areas) has coincided with a huge out-migration of upperincome whites, there is only one possible result in the larger American cities-a substantial expansion of the residential areas occupied wholly or partly by non-whites. The present situation in such cities thus indicates two seemingly contradictory trends, an increasing concentration in the principal non-white areas, and a spilling-out around the edges. Whether the result will be more or less "Black Belt" concentration, with all that that means for inter-racial relations, remains to be seen.

Moreover, overt trends towards racially integrated residential areas are also evident, though still in a relatively small way. The principal example is, of course, the successful policy of full integration in the public housing projects in many Northern and Western cities-now including most of the largest cities in the country. Moreover, as indicated above, a comparative study of the results of integrated and semi-segregated policies in similar projects in two neighboring North-Eastern cities established the point definitively that a policy of integration had strikingly better results for inter-racial amity-so conclusively that the other city promptly adopted the integrated pattern. ${ }^{31}$

As for private housing, open violence has occurred around the edges of expanding Negro areas in some cities; yet here too there are also signs of a more successful pattern. As Negroes inevitably spread out from their existing areas, the result may be either an increase in the segregated area, or integration into a stable "mixed" neighborhood. A recent survey in San Francisco indicated that in many instances non-whites had moved into "white" neighborhoods without incident, and in fact often without even being noticed. ${ }^{32}$ Even in Detroit and Chicago, two of the prin-

also W. E. B. Dubois, The Philadelphia Negro (1899); Robert A. Warner, New Haven Negroes (1940).

${ }_{30}$ The literature on this subject is voluminous. ROBERT C. WEAver, THE NEGRo GHETro (I948), is excellent and comprehensive. See also St. Clair Drake and Horace R. Caxton, Black Metropolis (I945).

${ }^{31}$ See footnote 9 stupra.

${ }^{32}$ See N. Y. Times, Dec. I3, I954, p.I, col. 7. One quarter of those interviewed did not know that there had been non-white in-migration into their neighborhood, and three-quarters did not mention 
cipal trouble areas, there have been recent examples of successful cooperative effort in local areas, including even at least one instance of integration of Negroes into a white property owners' association. ${ }^{33}$

In short, there are at present definite trends both toward and away from residential segregation on a racial basis.

5. Economic. While some progress is thus being made in reversing the trend towards racial segregation in housing, the trend in new residential development is definitely, and perhaps increasingly, towards increased segregation by economic groups. Most new suburban subdivisions are planned within a single price range, usually for upper-middle income whites but sometimes for lower-middle income whites. As a matter of law, public housing projects are limited to lower-income groups. ${ }^{34}$ Moreover, in the central areas of the bigger cities, most new residential construction is either luxury or low-rent public housing. ${ }^{35}$ As a result of these and other similar trends, it is increasingly true that Americans are living and coming into contact only with those of the same general income level.

However, segregation by economic groups in residential areas is not really a different problem from racial or ethnic segregation. Since most minorities are heavily concentrated in the lower-income groups, a successful policy of economic segregation will automatically bring about a very high degree of racial and ethnic segregation. In effect, economic segregation is not only the easiest but also the most effective form of racial and ethnic segregation; and so a high-rent housing project often turns up as an attempted "barrier" against expansion of a non-white area. A successful policy of economic, and therefore largely of racial and ethnic segregation, therefore provides in effect multiple protection against more democratic living.

In some cities conscious efforts have started to counteract these trends. For ex-

the fact in a lengthy discussion. About one-fifth were actively friendly, about the same number hostile, and the rest more or less indifferent.

${ }^{33}$ Recent studies have shown similar trends in several of our great cities, including a rapid increase in non-white population-with a large part of the increase going into the "Black Belts," and so an increase in the number of almost solidly "non-white blocks," and yet also considerable scattering into new areas, and so an increase in the number of areas with some non-white population. While concentration is the most important fact, it must not be overemphasized; in 1950 about one-third of the blocks in Philadelphia and San Francisco had some non-white population. However, these studies do not provide any definitive answer on two critical problems-to what extent existing inter-racial ncighborhoods, with something like a half-and-half division, are maintaining their stability, and to what extent expansion around the edges of a non-white area is resulting in integrated communities or in enlargement of the segregated area. See Citx of Philadelphia, Commission on Human Relations, Philadelpina's Negro Populatton, Facts on Housing 4-13, 35-37 (1953); publications of City of Detroit, Mayor's Interracial Committec, particularly Schermer, The Transitional Hotssing Area (1952), and also Distribution of Negro Population in Detroit, The Detroir Focus, May-June, 1952; New York CitX Plannine Commission, Report on Tenant Relocatton 23 ff. (1954); San Francisco Dep't of City Plannino, The Population of San Francisco: A Half-Century of Change 19-20 (I954).

${ }^{84}$ U.S. Housing Act of 1937, 50 STAT. 888 (1937), as amended, 63 STAT. 429 (1949), 42 U.S.C. \$140I ff. (1952); see Beckett v. Housing Authority of Baltimore City, I98 Md. 71, 81 A.2d 215 (1951) and Neufeld v. O'Dwyer, I92 Misc. 538, 79 N.Y.S.2d 53 (Sup. Ct. 1948).

${ }^{\mathbf{3 5}}$ For example, with new development almost wholly concentrated in luxury and low-rent public housing, Manhattan is increasingly becoming a residential area for the highest and lowest-income groups, with the middle class squeezed out. 
ample, a middle-income housing project may be purposely located next to a low-rent public housing project, in order to restrict the trend towards economic ghetto-ism.

In addition to the direct implications for democratic living, the trends towards upper- and middle-class white concentrations in the suburbs, and lower-class white and non-white concentration in the cities, have other and broader implications. Inexpensive and even moderate-priced housing needs low-cost vacant land. ${ }^{36}$ If the great mass of the lower-income groups, who are most in need of such housing, are excluded from the very areas where vacant land is available and being developed, most of them will in fact be forced to stay in the slums for a long period in the future. Moreover, particularly in view of the simultaneous flight of higher-income groups to the suburbs, the big cities, where most of such slums are located, are financially least able to take care of the heaviest burdens for locally financed public services-i.e., for the education and health of the next generation.

Economic segregation in residential areas therefore also creates problems on racial and economic segregation, on the possibility of any substantial amount of new inexpensive housing, and on public education and health.

6. Age. Segregation of residential areas by age groups is also markedly increasing, since most new areas are developed primarily for young married couples with young children-i.e., with 2-, 3- or sometimes 4-bedroom houses. The principal significance of this for planning lies elsewhere than in the realm of democratic values. In addition to the loss of the cultural stimulus of different age groups, such a trend inevitably creates a most serious problem in planning public facilities. If a large new area is developed all at once for a single age group, the problem of providing school facilities is almost insoluble. Huge overloads are almost certain to exist in the schools as enrollments climb to peak-and, if anywhere near enough schools are built at this time, these are likely to be half-empty thereafter. ${ }^{37}$

\section{III}

\section{Legal Control over the Development of the Environment}

\section{A. Residential Land Use Control-In General}

In order to understand and evaluate the planning devices and the resulting constitutional decisions which have arisen out of the trends discussed above, these must be analyzed against a background of the various goals of land-use control in residential areas. What sort of an environment are we trying to create, and why? The literature of city planning is rather long on elaborate statements of abstract goals, and very short on discussions of specific aims and clear-cut ideas of how to go about approaching them.

The principal aims of residential land-use control, including zoning ordinances, enforcement of restrictive covenants, and common-law nuisance actions, are as follows:

\footnotetext{
${ }^{30}$ Except where there is a large subsidy to cut inflated slum costs.

${ }^{37}$ Some communities have avoided this dilemma by building less expensive buildings for temporary school use, and later conversion to other purposes, including housing or some other community use.
} 
I. Protection against physical dangers. For example, a munitions dump does not belong next to a residence. While not common, such problems are obviously of primary importance when they do arise.

2. Protection against the common-law nuisances. These include noise and vibration, the various forms of air pollution (smoke, fumes, dust, etc.), excessive heat and cold, glaring lights, etc. While more common than the actually dangerous activities, these factors still do not play as important a role in land-use regulation as is sometimes thought.

3. Protection against heavy traffic. Restrictions on those establishments which create either substantially more traffic, or different kinds of traffic, from the characteristic establishments of an area, constitute a really major factor, both in residential density regulations and in use classification for residential (and in fact for other) zoning districts. Since traffic accidents are so large a factor in safety, and since traffic plays so dominant a role in urban noise and fumes, this might be considered a special case of numbers $\mathrm{I}$ and 2 above. As argued in Mr. Fonoroff's article in this symposium (see pp. 238-254, supra), this factor plays a much more important part in zoning regulations than has generally been realized, particularly by the courts.

4. Protection against congestion. Even apart from considerations arising from vehicular traffic, there is also a somewhat different type of problem-the protection of the relative degree of peace and quiet in a residential neighborhood against the bustle and noise which result from the presence of large numbers of people and their movement. This is a central element in residential density regulations, and also in several types of use regulations.

5. Protection of light and air, and of open space. Density regulations do set a general level of potential light and air and of open space around residences. Yet density regulations do not really provide effective control over such other factors, for-depending on the design-the available amount of each of these may vary considerably, within each level of density. Specific zoning devices are therefore appropriate in connection with each of the three major purposes of bulk zoning - to restrict density, to provide for light and air, and to provide for open space. Actually, one of the major curses of American zoning has been the usual attempt to provide both density control and open space largely through the medium of devices which are more appropriate to provide light and air-i.e., yard, court and height regulations.

6. Protection of morals. While protection of morals is generally a minor element in zoning, it is sometimes invoked to justify special restrictions on taverns, pool halls, and other establishments thought to lead the young into bad habits. Normally these regulations will appear in the use regulations of commercial districts mapped near residential areas or near various types of community facilities. ${ }^{38}$

\footnotetext{
${ }^{38}$ Requirements in Connecticut for a specified distance between establishments selling intoxicating liquor have resulted in much litigation. See, for example, Stavola v. Bulkeley, 134 Conn. I86, 56 A.2d 645 (1947); Delaney v. Zoning Board of Appeals of City of Hartford, r34 Conn. 240, 56 A.2d 647 (I947).
} 
7. Protection against "aesthetic nuisances." This involves structures or establishments which are offensive, not to the sense of hearing or to the sense of smell, but to the sense of sight. The general rule of constitutional law is supposed to be that, while this aesthetic factor may be taken into consideration in drawing zoning regulations under the police power, nevertheless "you cannot zone for aesthetics alone." This doctrine is based on a false conception of what goes on in zoning, and leads to some rather odd results. Because of this supposed rule, great difficulty is encountered in zoning against billboards (particularly in agricultural and commercial areas) and against other structures which are real eyesores. On the other hand, other regulations which are really much more drastic aesthetic controls are quite common and are often upheld regularly, though ostensibly on other grounds. ${ }^{39}$

8. Protection against "psychological nuisances." In other instances, there are strong objections to certain aspects of the environment, based not upon concrete physical factors but upon irrational fears and dislikes. There are two quite different types of situations in which this may occur. The first is the invasion of a residential environment by certain types of establishments around which irrational fears tend to center. Funeral parlors provide the obvious example of this type. The second type involves the entrance into residential neighborhoods of groups of people who are disliked for one reason or another-usually because of racial, ethnic or lower economic status. Regulations directed at the latter type of factors are much more common than is generally realized. The impolite term for this is "snob zoning."

9. Regulation of the Rate of Development and Protection of the Municipal Tax Base. Finally, certain types of zoning controls are concerned with regulating the rate and amount of development, particularly in order to keep some control over the resulting demand for public services and so the burden on the municipal tax base. Mr. Fagin's article in this symposium spells out some of the problems involved here (see pp. 298-304, supra).

While the factors discussed above comprise the major goals of residential landuse control, any discussion of such control would be incomplete without referring to two other alleged factors which are frequently cited as major considerations, in zoning opinions and elsewhere-protection of property values, and protection of the

\footnotetext{
${ }^{\text {so }}$ A colleague once remarked, during an exhaustive discussion of the whys of certain zoning districts: "The whole thing is really a matter of aesthetics and traffic, isn't it?-that is, apart from keeping out a few nuisance industries." This was a pardonable exaggeration of the realities of the situation. The real concern in many of the usual zoning regulations is how an area looks, particularly from the street side; and a large proportion of these involve quite stringent regulations. However, their primary purpose is often obscured, either by abstract phrases (such as "protection of property values" and "protection of the character of a neighborhood"-see pages 334,344 infra), or by pretending that the regulation in question is motivated by some other reasons. (See note 2 supra). The ironical result is that very drastic aesthetic regulations are often upheld on the ground that they are really something else-whereas, with structures (such as billboards and neon signs) which involve real eyesores, the aesthetic motive is so clearly dominant that a great deal of trouble is encountered in upholding such regulations. What is supposed to be the traditional general rule of constitutional law, that "you cannot zone for aesthetics alone," is therefore pretty much nonsense. Moreover, the Supreme Court has just done what it could to abolish the traditional rule in Berman v. Parker, 348 U.S. 26 (1954).
} 
"character of the neighborhood." The very extensive discussions of land-use controls in these terms contribute remarkably little understanding of what is going on; for each of these two factors is derivative, merely reflecting the presence of one or more of the other factors discussed above-and thus may, or may not, refer to something which is a proper subject for public regulation.

Protection of property values is of course the more important of these two. Anyone who has had to deal with local municipal problems is all too conscious of the extent to which most communities' ability to provide services still depends upon real property taxes, which in turn depend upon property values. But this is not the same as saying that a discussion concentrating on the immediate effect on property values is a very useful way to find out what is going on. What is said here is therefore in no sense an argument against protecting property values. The point is merely that it does not make sense to limit one's attention to such derivative factors, without looking into those basic factors which affect (or are thought to affect) property values.

When the argument is made that property values will be affected, what is meant is simply that some factor is present which some people may dislike, and which may therefore tend to result in a net reduction in the number of people interested in buying property in the area affected-thus tending to push values down. The real question is always a simple one-what is the factor which is involved? Some factors which affect property values (or which are thought to do so) are legitimate subjects for public regulation, by zoning or otherwise; others are not. For example, the invasion of factories and the movement of Negroes into a residential neighborhood both may be thought to affect property values. ${ }^{40}$ Yet one is obviously a proper subject for zoning protection, while the other is not. ${ }^{41}$ The fact that property values may be affected gives reason to look into the situation, but by itself tells nothing about whether governmental protection is appropriate.

The argument about protecting the "character of a neighborhood" involves similar problems. The question here is equally simple: what characteristics of an area are involved? Again, some characteristics present proper subjects for governmental action, while others do not; it is necessary to look into the situation further to find out first what is going on, and then whether something should be done about it. Actually the phrase "the character of a neighborhood" is usually used to refer to one of two things-either aesthetic characteristics, or those social characteristics which create some local opposition and thus fall into the category of "psychological nuisances." In other words, use of this phrase is usually a warning that either aesthetic zoning or snob zoning is involved.

B. Residential Segregation and Constitutional Law

There are several lines of cases which have arisen, directly or in part, out of the

10 The theory that Negro movement into a "white" residential area results in a decline of property values has been subjected to increasing criticism lately. See for example Laurenti, Effects of Non-White Purchases on Market Prices of Residences, 20 APPRAIsal Jour. 314 (1952).

${ }^{11}$ See discussion of racial zoning on page 336 infra. 
above-described racial, ethnic and economic-group conflicts within residential areas. These lines of cases may be divided into three general types, differing on the extent to which private and public action are involved. The first involves direct governmental action, by statute or otherwise, to regulate private arrangements by forbidding certain racial, ethnic or economic groups from living or owning land in specified areas. The second involves the provision of public facilities (schools, housing, and the like) for such groups along with other groups. The third, between the other two, involves public assistance for private development (primarily in housing), and the implications of such assistance for segregation.

In all of these, the relation between public and private action plays an important role. For, in each of these lines of cases, one significant common element is involved. In each instance the traditional forms of residential discrimination by private action-such as refusal by owners to rent or sell, "codes of ethics" promulgated by and for real estate brokers, ${ }^{42}$ withholding of credit by financial institutions, property owners' associations, and other highly organized pressures-have been inadequate to preserve the segregated pattern; and as a result the machinery of government has been invoked to help promote or protect residential segregation.

The first problem in reviewing these lines of decisions is therefore to have a clear understanding of the scope and legal significance of governmental, as contrasted with private, activity in these realms. In this connection understanding starts from a consideration of the broader implications of the great racial covenants cases. ${ }^{43}$ For, quite apart from their epoch-making significance in relation to minority housing, these decisions also represented a major change of viewpoint towards the role of government-another major step away from the laissez-faire theory of the "passive policeman state." The broad principle established in these cases is that all forms of governmental activity, including specifically the enforcement of private contracts, constitute active intervention by the state and so "state action," which is subject to the guarantees of equal treatment embodied in the Fourteenth Amendment.

The question in the cases to be considered next is whether all processes involving any participation by government are also subject to the constitutional guarantees of equal treatment-or, if not, where to draw the line.

\section{Racial and Ethnic Segregation-Outright Legal Requirements Applying to Private Development}

Repeated attempts to enforce direct residential segregation along racial (and, to a lesser extent, ethnic) lines have resulted in prolonged and intensive litigation, and so a substantial body of constitutional law has grown up in this area. The law is now quite clear that such direct governmental action on behalf of segregation is unconstitutional. The problem is whether this has set up a general rule of law that

"A particularly striking example of organized private action by real estate groups, in effect to "zone" a city into "white" and "Negro" areas, is the map issued in I944 by the St. Louis Real Estate Exchange, showing areas in which real estate brokers could sell land to Negroes. See Herman H. LoNg and Charles S. Johnson, People vs. Property 60-6I (I947).

${ }^{43}$ Shelley v. Kraemer, 334 U.S. I (1948); and see Hurd v. Hodge, 334 U.S. 24 (1948). 
restrictions on the occupancy of residential areas may not be directed against specific groups of people. ${ }^{44}$

I. Racial Zoning. Conflicts over residential segregation, and the resulting constitutional law on the subject, have both been largely a twentieth century affair. However, a startling early case arose in 1890 , when a local ordinance ordered the entire Chinese population of San Francisco to move to another area-an order promptly invalidated by the federal courts. ${ }^{4 \overline{5}}$ However, it was when the great movement of Negroes, northward and to the cities, began about rgro that racial zoning ordinances were enacted in a number of cities in the Southern and Border states. ${ }^{40}$ Such ordinances allocated residential areas to either white or Negro occupancy, usually according to the race of the existing majority on each block. ${ }^{47}$ In $x 917$, the Supreme Court held that such ordinances were unconstitutional, originally primarily on the ground that they constituted an unreasonable restriction on the rights of the white vendor to sell his property. ${ }^{48}$ In spite of this decision, similar ordinances have been repeatedly passed in Southern cities almost right up to the present, including several ingenious but transparent subterfuges-which have been consistently struck down in court. ${ }^{49}$

2. Racial Covenants. Since outright racial zoning restrictions were thus in rather bad repute even legally, racial restrictive covenants were widely invoked to provide legal protection for segregated residential areas. Here again a late nineteenth century California case, disconnected from the main stream of the law, was prophetic, since the federal courts there refused to enforce an anti-Chinese covenant on the ground that such action would violate the equal protection clause. ${ }^{.0}$ However, starting about

4 The equal protection clause in the Fourteenth Amendment of the Federal Constitution is directed against state action, and its guarantees apply to protect all persons, not merely citizens. Technically there is no such requirement in the Fifth Amendment applying to action by the Federal Government. But see Bolling v. Sharpe, 347 U.S. 497 (I954).

${ }^{45}$ In re Lee Sing, 43 Fed. 359 (C.C.N.D. Cal. 1890).

10 These ordinances preceded the first American comprehensive zoning law, the New York law of x916. The statement sometimes made, that racial zoning is another example of an originally beneficial legal device which was later perverted to other and anti-social purposes, is therefore hardly correct.

${ }^{47}$ See State v. Gurry, I2I Md. 534, 88 Atl. 546 (r913); Carey v. City of Atlanta, I43 Ga. I92, 84 S.E. 456 (I915); State v. Darnell, I66 N.C. 300, 81 S.E. 338 (rgr4) (with serious analysis of implications); Hopkins v. Richmond, II7 Va. 692, 86 S.E. I39 (I9I5); Harden v. City of Atlanta, I47 Ga. 248, 93 S.E. 401 (1917); Harris v. City of Louisville, $165 \mathrm{Ky} .559$, I77 S.W. 472 (1915), reversed along with Buchanan v. Warley, 245 U.S. 60 (I917).

${ }^{48}$ Buchanan v. Warley, 245 U.S. 60 (1917).

${ }^{48}$ Jackson v. State, $132 \mathrm{Md}$. 311, I03 Atl. 9ro (rgr8); Irvine v. City of Clifton Forge, 124 Va, 78r, 97 S.E. 3 ro (rgr8); Tyler v. Harmon, I58 La. 439, x04 So. 200 (1925), I60 La. 943 , 107 So. 704 (1926), reversed per curiam, 273 U.S. 668 (I927) (requirement of written consent of majority of those of opposite race living nearby); City of Richmond v. Deans, 37 F.2d 712 (4th Cir. 1930), affirmed per cturiam, 28x U.S. 704 (1930) (prohibition against living near those with whom inter-marriage is forbidden); City of Dallas v. Liberty Annex Corporation, 19 S.W.2d 845 (Texas Civ. App. 1929) (alleged agreement between leaders of both races on division of city's residential areas); Allen v. Oklahoma City, I75 Okla. 421, 52 P.2d ro54 (1935); Clinard v. City of Winston-Salem, 217 N.C. 1x9, 6 S.E.2d 867 (1940) (in regular zoning law); Monk v. City of Birmingham, 87 F. Supp. 538 (N.D. Ala. 1949), aff'd, 185 F.2d 859 (5th Cir. 1950), cert. denied, 341 U.S. 940 (195I) (the lattcr ordinance reportedly allocated $x 6$ per cent of the land in Birmingham for the 40 per cent of its population which was Negro).

${ }^{50}$ Gandolfo v. Hartman, 49 Fed. I8r (C.C.S.D. Cal. 1892). 
1920, anti-Negro racial covenants were uniformly enforced in a long series of decisions, extending over some thirty years-which even achieved the dignity of a dictum in a Supreme Court opinion" ${ }^{51}$ and a series of A.L.R. annotations ("the courts are in agreement"). ${ }^{52}$ The theory in these cases was of course that such enforcement represented nothing more than carrying out the provisions of a private contract, which was regarded as a more or less ministerial task. The only exception was a supremely ironical one; in some states it was held that, while such covenants could not prevent Negroes from buying property, they could prevent them from using it. ${ }^{\text {.3 }}$

However, after the Second World War, the housing shortage and the continued migration from the rural South resulted in a rash of new racial covenants cases, ${ }^{54}$ and enforcement of the covenants was challenged on all sorts of grounds. The arguments in these cases concerned allegations that such covenants involved unreasonable restraints upon alienation, were void for vagueness, violated public policy, failed to provide equal protection of the laws, and conflicted with the Civil Rights Act and with national obligations under the U.N. Charter. ${ }^{55}$ However, the guarantee of equal protection of the laws was generally recognized as the real issue; and, on a serious level, the debate on this point was ended by the great dissenting opinion of Judge Edgerton in Hurd v. Hodge in the District of Columbia Court of Appeals. ${ }^{56}$

It has been contended that enforcement of covenants which exclude a race from a neighborhood does not involve discrimination because it permits reciprocity. This amounts to saying that if Negroes are excluded from decent housing they may retaliate by excluding whites from slums.

On appeal, the Supreme Court overruled the massive body of precedent accumulated over so many years and held (in Shelley $v$. Kraemer) ${ }^{57}$ that the equal protection clause prevented the enforcement of racial covenants by injunction or eviction orders in the state courts, and (in Hurd v. Hodge) ${ }^{58}$ that the Civil Rights Act had the same effect (at least for citizens) in the federal courts of the District of Columbia. These decisions (particularly Shelley) rested squarely on the premise that such a judicial order itself represented action by the State, and that for this purpose it made no

\footnotetext{
Ex Corrigan v. Buckley, 27I U.S. 323, 33 I (x926).

${ }^{62} 162$ A.L.R. 180 (1946); and see also 9 A.L.R. I20 (I920); 66 A.L.R. 53 I (I930); II4 A.L.R. 1237 (1938). But compare 3 A.L.R.2d 466,467 (1949).

${ }^{23}$ See 3 A.L.R.2d 466, 490 (I949).

"See Kemp v. Rubin, 188 Misc. 310,69 N.Y.S.2d 680 (Sup. Ct. 1947), reversed mem., 273 App. Div. 789, 75 N.Y.S.2d 768 (2d Dep't r947), aff'd mem., 298 N.Y. 590, 8I N.E.2d 325 (r948); Sipes v. McGhee, 316 Mich. 614, 25 N.W.2d 638 (1947), reversed, 334 U.S. I (1948); Perkins v. Trustees of Monroc Ave. Church of Christ, 79 Ohio App. 457, 70 N.E.2d 487 (I946); Kraemer v. Shelley, 355 Mo. 8r4, I98 S.W.2d 679 (1946), reversed, 334 U.S. I (1948); Schwartz v. Hubbard, I98 Okla. I94, I77 P.2d II7 (r947); Eakers v. Clopton, I99 Okla. 99, I84 P.2d 247 (1947); Hurd v. Hodge, I62 F.2d 233 (D.C. Cir. I947), reversed, 334 U.S. 24 (1948).

${ }^{65}$ See discussion in Zoning and Planning Notes, The American City, May 1947, p. I03; id., Aug. 1947, p. I25; id., Sept. 1948, p. I4I.

${ }_{50}{ }_{162}$ F.2d 233, 239 (D.C. Cir. 1947), reversed, 334 U.S. 24 (1948).

${ }^{67} 334$ U.S. I (1948).

334 U.S. 24 (1948).
} 
difference whether the legal basis for the order was derived from an ordinance or from common-law precedent. In the last six years this decision has had considerable effect in opening up new areas, at least for upper-class Negro occupancy.

Nevertheless, even after this, one more major legal obstacle turned up. Rather incredibly, the state courts still split on the question as to whether a judicial order to pay money damages, for violation of a covenant, likewise represented the proscribed "state action" and so was subject to the equal protection clause. ${ }^{50}$ However, in 1953 in Barrows v. Jackson the Supreme Court finally settled this point too. ${ }^{.0}$

Covenants directed against ethnic groups have been rather less common, and have also had more difficulty in court, for no particular logical reason. While there have been few opinions, anti-Semitic covenants were said to be invalid by the courts even during the heydey of racial covenants. ${ }^{61}$

Now that the great legal battle on racial covenants is over, the law on residential segregation has turned to other areas of conflict. At least one of these involves an even more drastic series of direct prohibitions on land-ownership.

3. Alien Land Laws. The alien land laws in twelve Western states go beyond even racial zoning by forbidding certain types of aliens to own any land anywhere in the state. ${ }^{62}$ There is no overt reference to racial criteria in these laws. However, the subterfuge was fairly transparent, for these laws took over, from the naturalization laws, a classification which is clearly racial-by forbidding land-ownership by those aliens who were ineligible for naturalization, which originally included Japanese, Chinese, and certain other Asiatics. The present constitutional status of such laws is interesting. In a series of test cases in $1923,{ }^{63}$ the Supreme Court upheld them on really extraordinary grounds-essentially by adopting the proposition that, since the obligations of a medieval feudal landowner included military duties, therefore (!) a state government in twentieth century America also has a special interest in the loyalty of its landowners, and may for this reason forbid ownership of land, not by all aliens, by by certain racial groups who were ineligible for naturalization. Revival of enforcement of this legislation during and after the Second World War reached what must be a new low in petty meanness, and resulted in a new

${ }^{59}$ Weiss v. Leaon, 359 Mo. 1054, 225 S..W.2d I27 (1949) (for enforcement); Roberts v. Curtis, 93 F. Supp. 604 (D.D.C. x950) (against enforcement); Correll v. Earley, 205 Okla. 366, 237 P.2d ror7 (195I) (for enforcement); Phillips v. Neff, 332 Mich. 389, 52 N.W.2d 158 (1952) (against enforcement); Barrows v. Jackson, II2 Cal. App.2d 534, 247 P.2d 99 (r952) (against enforcement), aff'd, 346 U.S. 249 (1953). On brokers' commissions and purchaser's right to recover a deposit, sce Savage v. Parks, I00 A.2d 450 (D.C. Mun. Ct. App. I953).

${ }^{60} 346$ U.S. 249 (x953).

${ }^{61}$ Miller v. Jersey Coast Resorts Corporation, 98 N.J.Eq. 289, 297, 130 Atl. 824, 828 (Ch. 1925) (anti-Semitic covenant deseribed as invalid in dictum). Ironically, more recently a Virginia covenant directed against "persons who customarily observe the seventh day of the week as the Sabbath" was first invoked against a Seventh-Day Adventist. See also $R e$ Drummond Wren, [I945] Ont. L.R. 778.

${ }^{62}$ California, Arizona, Louisiana, New Mexico, Idaho, Montana, Oregon, and Kansas, all similar, passed between 1913 and 1925; Utah and Wyoming, passed in r943; Washington (1889) and Arkansas (r943), following a different form.

${ }^{63}$ Terrace v. Thompson, 263 U.S. I97; Porterfield v. Webb, 263 U.S. 225; Webb. v. O'Bricn, 263 U.S. 313 ; Frick v. Webb, 263 U.S. 326 -all in 1923. 
series of constitutional decisions. A rebuttable statutory presumption in the California alien land law provided that conveyances of land to infant children (who could be citizens and thus lawful land-owners under the statute) were made to evade the law; and in 1948 this presumption was invalidated by the Supreme Court, in a decision which (by a 5 to 4 vote) avoided a direct re-appraisal of the substantive issue. ${ }^{64}$ However, since then the Supreme Courts of Oregon and California have, on their own initiative, held that, under modern views of constitutional law, the decisions upholding the alien land laws have been in effect overruled "sub silentio,"65 and so such laws are now unconstitutional; ${ }^{66}$ and Congress, by repealing the restrictions on naturalization of Asiatics, has made the alien land laws of no effect. Thus ends one of the more inglorious episodes in American legal history.

\section{Racial and Ethnic Segregation-in Public Facilities}

Another major constitutional problem is whether segregation in public facilities in itself constitutes discrimination, and so a denial of equal protection of the laws. During the post-Reconstruction period, when statutory discrimination against Negroes was increasing in the South, the Supreme Court followed the dominant trend of the times and laid down the "separate but equal" doctrine-i.e., that legal requirements for separate facilities (in the original case, transportation facilities) were constitutional so long as the facilities provided were substantially equal. ${ }^{67}$ Yet this doctrine has been severely shaken by the recent decision against segregation in the public schools. ${ }^{68}$

r. Schools. Recent developments on segregation in education are of special significance in relation to segregation in residential areas, partly because these are two vital areas of human contact, partly because residential segregation has so great an influence on segregation in the schools and other facilities. In the North and West most educational facilities have been more or less fully integrated for many years, except that school district lines are often drawn so as to result in segregated schools. However, school segregation has been mandatory in the Southern states, and permissive in a few adjacent areas. The existence of the "separate but equal" doctrine did not prevent the actual inequalities from being very striking. This is hardly surprising; for a major raison d'être of that system, along with its background in race prejudice, has been that it made it possible for the dominant whites to chisel on facilities for Negro children, in order either to save money or to shift funds so as to provide better education for their own children.

The triumphant constitutional attack upon this segregated system began in con-

ot Oyama v. California, 332 U.S. 633 (1948). Compare Takahashi v. Fish and Game Commission, 334 U.S. 4 ro (1948).

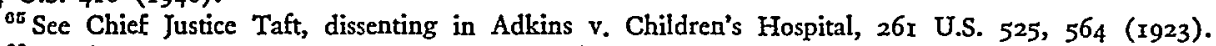

${ }^{00} \mathrm{Namba}$ v. McCourt, 185 Ore. 579, 204 P.2d 569 (1949); Sei Fujii v. State of California, 217 P.2d $48 \mathrm{r}$ (District Ct. of Appeal 1950), rehearing denied, 218 P.2d 595 (District Ct. of Appeal I950), aff'd, 38 Cal.2d 718, 242 P.2d 6r7 (1952); Masaoka v. People, 39 Cal.2d 883, 245 P.2d 1062 (1952). Compare Palermo v. Stockton Theatres, 32 Cal.2d 53, I95 P.2d I (x948).

${ }^{\circ 7}$ Plessy v. Ferguson, 163 U.S. 537 (1896).

${ }^{\circ 8}$ Brown v. Board of Education of Topeka, 347 U.S. 483 (I954). 
nection with higher education, ${ }^{69}$ and culminated in the recent epoch-making decision in Brown v. Board of Education that segregation in public educational facilities necessarily involves discrimination, and thus violates the equal protection clause. The rationale of this opinion, ${ }^{70}$ that education is so basic an area of life that segregation there is intolerable in a democratic society, has an obvious application to segregation in living accommodations.

No final Supreme Court decree has yet been formulated to implement the Brown decision, and there is a wide range of choices. ${ }^{71}$ However, it must always be remembered that the best efforts to implement such a policy are bound to be relatively ineffective, as long as the residential areas served by the schools continue to be segregated. For residential segregation is a basic problem not only for its own implications, but because it is likely to determine the effectiveness of attempts to desegregate schools and other facilities.

To return to problems directly involving residential areas-now that the constitutional issues arising from direct governmental action to exclude certain groups from specific areas have been largely settled, the principal legal problems have shifted to a new area-discrimination in public and publicly aided housing. For when government undertakes either to build new housing, or to provide various types of assistance for those who do so, a stand necessarily has to be taken, one way or the other, on the segregated pattern of occupancy of much urban land. And a decision to exclude certain groups from public or publicly aided housing involves legal issues at least as serious as those discussed above.

2. Public Housing. Since most minority groups are heavily concentrated in the lower-income groups, access to public housing is much more important to most members of minority groups than access to any other type of new housing. The public housing program has provided a substantial amount of housing for low-income Negroes, generally in accordance with their relative need-i.e., in proportion to the percentage of Negroes in the lower-income groups served by the program, which is of course much larger than the percentage of Negroes in the total population. However, the majority of public housing projects all over the country have been either

${ }^{\circ 0}$ Missouri ex rel. Gaines v. Canada, 305 U.S. 337 (1938); Sipuel v. Board of Regents of University of Oklahoma, 332 U.S. 63 I (x948); Sweatt v. Painter, 339 U.S. 629 (1950); McLaurin v. Oklahoma State Regents for Higher Education, 339 U.S. 637 (1950). Compare the older cases of Cumming v. Board of Education of Richmond County, I75 U.S. 528 (r899); Gong Lum v. Rice, 275 U.S. 78 (1927).

${ }^{70}$ See 347 U.S. 483, 494-495 (I954): "To separate them [Negro children] from others of similar age and qualifications solely because of their race generates a feeling of inferiority as to their status in the community that may affect their hearts and minds in a way unlikely ever to be undonc. . . ."

"We conclude that in the field of public education the doctrine of 'separate but equal' has no place. Separate educational facilities are inherently unequal. ..."

See also the lower court decision in Belton v. Gebhardt, 87 A.2d 862 (Ct. of Chancery 1952), aff $d$, 91 A.2d $\times 37$ (Sup. Ct. $\times 952$ ), affirmed in the same procceding as the Brown decision.

71 For active steps toward integration, see the statements reported in the N.Y. Times, Oct. 27, 1954, p. 13, col. 6 (on investigation by state officials of alleged segregation in the schools in Englcwood, N. J.); id., Dec. 18 , 1954, p. 17, cols. 6-7 (on the closing of an all-Negro state school in Bordentown, N. J., to break up its segregated pattern); and $i d$., Dec. 24 , 1954, p. 15, col. 8 (on the creation of a special commission by the New York City Board of Education to consider whether further steps are necessary to deal with any possible segregation in the City's schools). 
segregated (by project) or semi-segregated (by building or stair-well)-i.e., in this one area the "separate but equal" formula has been followed more or less honestly. In some projects there has been outright segregation. In others, the device has been to reproduce the existing pattern in the area which has been cleared and rebuiltwhich may result in segregation or otherwise. Nevertheless, particularly since 1945 , many of the great Northern and Western cities, and a considerable number of the smaller ones, have followed the lead of New York City in adopting a fully integrated rental policy-i.e., apartments are rented all over the projects without regard to racial background. ${ }^{72}$ The number of integrated public housing projects has thus been increasing rapidly. Moreover, a number of decisions have held very recently that, following Brown v. Board of Education, segregation in public housing necessarily involves discrimination and therefore involves a denial of equal protection. ${ }^{73}$

\section{E. Racial and Ethnic Segregation-In Publicly Assisted Housing}

r. Urban Redevelopment. Under another program, pioneered in New York, Chicago, and Philadelphia, and powerfully stimulated by federal financial and technical aid since 1949, the powers of government (including eminent domain and technical assistance) are used for slum clearance, and the land is then sold for redevelopment, usually by private action, and often with at least partial local taxexemption. ${ }^{74}$ Because of the various forms of governmental aid involved, the issue has been sharply drawn on discrimination in such projects. In Stuyvesant Town in New York, the first really large project (with a population of around 25,000), which had the benefit of both eminent domain and partial tax exemption, the developer (the Metropolitan Life Insurance Company) announced an all-white renting

${ }^{73}$ New York, Chicago, Los Angeles, Cleveland, Washington, Boston, San Francisco, Pittsburgh, Buffalo, Seattle, Newark, and Wilmington are among the large cities which have now adopted the policy of fully integrated public housing projects.

${ }^{73}$ In Banks v. Housing Authority of City and County of San Francisco, r20 Cal. App.2d x, 260 P.2d 668 (1953), cert. denied, 347 U.S. 974 (1954), San Francisco public housing projects started before 1949 were still segregated by a requirement of conformity to the previous neighborhood pattern, with one small project so far allocated to Negro occupancy; and at the end of the total program, public housing was supposed to be available to all groups according to their proportionate needs. The court held that this arrangement violated each individual Negro's right to equal protection, and the Supreme Court refused to review. In Taylor v. Leonard, 30 N.J. Super. Ix6, ro3 A.2d 632 (Super Ct. 1954), Negroes were segregated into part of one Elizabeth project, with about 9 per cent of the total public housing dwelling units available for their use-allegedly corresponding to the proportion of Negroes in the city's population. The court held, rather sharply, that this violated both federal and state constitutions. In Vann v. Toledo Metropolitan Housing Authority, II3 F. Supp. 2 ro (N.D. Ohio I953), the opinion again went against segregation, although the practice was discontinued while the action was pending. In Jones v. City of Hamtramck, I2I F. Supp. I23 (E.D. Mich. I954), the court granted a summary judgment forbidding discrimination against Negroes in the city's first housing project. Two older decisions split on segregation in public housing: Seawell v. MacWithey, 2 N.J. Super. 255, 63 A.2d 542 (Super. Ct. 1949) (against segregation), reversed on other grounds, 2 N.J. 563, 67 A.2d 309 (x949); Favors v. Randall, 40 F. Supp. 743 (E.D. Pa. r94I) (for segregation). See also Kankakee County Housing Authority v. Spurlock, r20 N.E.2d 561 (IIl. 1954) (allegation, as a defense in eminent domain proceeding, that project would be segregated, held not proven).

${ }^{74}$ Sce Housing Act of 1949, 63 STAT. 413 ff. (I949), as amended, 68 Stat. 590 (r954), 42 U.S.C. §I44I (Supp. I954). 
policy. When this was challenged in court, it was held first that the challenge was premature, ${ }^{75}$ and then in effect that it was too late. In Dorsey v. Stuyvesant Town ${ }^{70}$ the latter decision, the New York Court of Appeals split 4 to 3, with Judge Bromley and the majority holding in effect that Metropolitan was a public benefactor, and a powerful dissent by Judge Fuld tearing the majority opinion to shreds but never quite developing a satisfactory alternative rationale on the basic question-how much state aid is necessary to bring a project under the sanctions applicable to "state action." If this nation-wide program of urban re-building is a success, the implications of such huge segregated projects are obvious enough; yet the Supreme Court refused to review this decision. However, in New York City a combination of public pressure and local legislation, first prospectively for future projects and then retroactively, ${ }^{77}$ forced Metropolitan to a reversal of the policy; and, despite dire predictions that such a policy would kill off any additional private redevelopment projects, the city continues to lead the nation in the volume of such projects. Discrimination has also been forbidden in future projects in several other areas, including the state of Pennsylvania and the city of San Francisco. ${ }^{78}$

2. F.H.A. The Federal Housing Administration has provided federal insurance of mortgages for a large proportion of private housing built during the last twenty years. The agency serves the private real estate market, and tends to reflect its attitudes. A problem immediately arises as to whether the power of government shall be used to insure mortgages on racially restricted property. In addition to doing this, for many years the F.H.A. concentrated almost entirely on "white" housing, and actually insisted upon anti-Negro racial covenants as a prerequisite to granting mortgage insurance. In short, the Federal Government became the prime mover in closing off newly developed land from minority housing. However, several years ago this policy was at least ostensibly reversed as a result of Administration pressure; and the F.H.A. has also recently bestirred itself to promote a relatively small amount of Negro housing, almost all segregated. ${ }^{79}$

In summary, then, use of the constitutional guarantee of equal protection to eliminate racial segregation is rapidly extending, especially in connection with segregation in education and in residential areas. Moreover, the distinction between public and private facilities is being more and more blurred as programs for joint public

${ }^{75}$ Pratt v. LaGuardia, 182 Misc. 462, 47 N.Y.S.2d 359 (Sup. Ct. 1944), aff'd mem., 268 App. Div. 973, 52 N.Y.S.2d 569 (Ist Dep't 1944), appeal dismissed, 294 N.Y. 842, 62 N.E.2d 394 (1945) (holding that the action was premature, since Metropolitan at that time had not yet adopted a definite policy on renting).

${ }_{70} 299$ N.Y. 512, 87 N.E.2d $54 \mathrm{r}$ (1949), cert. denied, 339 U.S. 981 (1950). Here the rationale of the majority opinion was that, since in 1943 it was common knowledge that discrimination was to be practiced in the project, the City and the Legislature must have deliberately approved of this-and, further, that this discrimination was put into effect without any "state action."

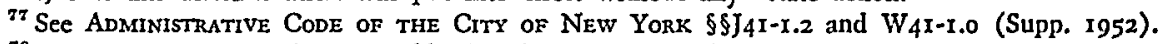

${ }^{78}$ See Pa. Stat. Ann. tit. 35, \$1664 (Purdon, Supp. 1953).

${ }^{79}$ On January 13, 1955, the National Association for the Advancement of Colored People started a lawsuit against the Levitts, on the ground that F.H.A. mortgage insurance on their huge new development at Levittown, Pennsylvania (see note 12 sitpra) should be held to preclude discrimination against Negroes in selling homes there. See N.Y. Times, Jan. 14, 1955, p. 23, col. 7. 
and private effort are developed. The exact outer limits of the effectiveness of these guarantees in publicly aided private facilities are not yet apparent.

\section{F. Segregation by Economic Groups}

In various areas, the law has thus been moving towards two general propositions. First, under the Constitution (and specifically under the equal protection clause) the facilities of government may not be used to prevent people from moving into and living in a given area, because of the color of their skin. Second, the now badly shaken "separate but equal" doctrine has no more place in living than in learning, so that segregation in residential areas (as in educational facilities) automatically involves discrimination.

The next question is an obvious one-whether the same principle applies to invalidate governmental action aimed at preventing people from moving into specified areas because of the size of their income. ${ }^{80}$ Clearly, in a society with democratic pretensions, one question is as basic as the other. And the second question raises serious questions about several types of residential land-use controls, primarily zoning regulations.

I. Overt Zoning for Economic Segregation. It is generally assumed that it would be unconstitutional for government to take direct and overt action to segregate residential areas by income levels-for example, by restricting specified areas to those with incomes over $\$ 10,000$, or to homes worth over $\$ 25,000$. There is some legal authority to this effect, though not much-because few communities have been so bold as to try this. ${ }^{81}$ However, restrictive covenants specifying the minimum value of a house have been very common-perhaps almost as common as racial covenantsand are generally presumed to be valid and enforceable, even now. In fact, this is often cited as an example of what can be done by covenants but not by zoning. However, the basic principle of Shelley $v$. Kraemer" is that "state action" includes the enforcement of contracts by the courts, and therefore that the courts cannot order something done to carry out a contract if the same would be unconstitutional when provided for by an ordinance. Under this principle, it is difficult to see what logic there is in the above-stated distinction between covenants and zoning.

2. By Subterfuge. If, however, residential segregation by income groups is attempted, not by specifying the minimum cost of a house, but by translating that minimum cost into the equivalent minimum size of house, then there is at least a

${ }^{80}$ The last twenty years have seen a long struggle to convert the Fourteenth Amendment from an instrument for economic protection of corporate groups back towards its original primary aim to prevent discrimination against under-privileged racial groups. It would be somewhat ironical if the courts were now to hold that, in this critical field of law, the guarantee of equal treatment is directed solely at preventing racial discrimination, and is not concerned with equal protection for other underprivileged economic groups.

${ }^{81}$ See Stein v. Long Branch, 2 N.J. Misc. I2I (Sup. Ct. I924); County Commissioners of Anne Arundel County v. Ward, $x 86$ Md. 330, 340, 46 A.2d 684, 688 (I946); Brookdale H'vmes v. Johnson, 123 N.J. Law 602, 606, ro A.2d 477, 478 (Sup. Ct. 1940), affd, r26 N.J. Law 5 6, I9 A.2d 868 ( $194 x$ ), overruled in the Wayne Township case (see note 84 infra).

${ }_{82} 334$ U.S. I (1948). 
possibility that all of the difficulties will suddenly and magically disappear. The size of a house is of course a direct function of its cost, or perhaps rather vice versa; in fact, building costs are rather generally quoted in terms of so much per square foot (or cubic foot). Thus, if residential building costs average \$15 a square foot, a regulation requiring a minimum of $\mathrm{I}, 000$ square feet of floor area accomplishes exactly the same thing as a regulation requiring houses to cost at least $\$ 15,000$. This point is so elementary, and the subterfuge so obvious, that in most American decisions local zoning regulations specifying the minimum permitted size of residential buildings (whether phrased in terms of cubage or of floor area) have generally been invalidated as a thinly disguised form of economic segregation. ${ }^{83}$ Nevertheless, in several recent decisions the situation has been sufficiently muddled, sometimes by a suddenly discovered local enthusiasm for public health regulations and sometimes by an undue deference to local autonomy, that minimum-building-size regulations have been upheld; ${ }^{84}$ and here again, in one important case, the Supreme Court refused to review. The constitutional status of such regulations must therefore be analyzed with some care. ${ }^{85}$

Several arguments are brought forward in support of minimum-building-size regulations. First, such regulations are said to protect property values and "the character of a neighborhood." As always, these phrases are merely another way of saying something else-in this case, that many home-owners would prefer not to have smaller houses nearby, either because they want economic segregation, or be-

${ }^{83}$ Senefsky v. City of Huntington Woods, 307 Mich. 728 , I2 N.W.2d 387 (1943) (1300 square feet); Frischkorn Construction Co. v. Lambert, 315 Mich. 556, 24 N.W.2d 209 (1946) (800 square feet at first floor level, and I4,000 cubic feet); Elizabeth Lake Estates v. Waterford Township, 317 Mich. 359. 26 N.W.2d 788 (x947) (500 square feet at first floor level, and 10,000 cubic feet); Hitchman v. Oalsland Township, 329 Mich. 33I, 45 N.W.2d 306 (195I) (800 square feet at first floor level, and 10,000 cubic feet); Baker v. Somerville, 138 Neb. 466, 293 N.W. 326 (1940) (2000 square fcet for onc-story houses) (and see Dundee Realty Co. v. City of Omaha, I44 Neb. 448, I3 N.W.2d 364 (I944)); American Veterans Housing Cooperative v. Zoning Board of Adjustment, 69 Pa. D. \& C. 449 (C.P. r949) (1400 square feet, with sliding scale of regulations for other districts); Appeal of Medinger, $377 \mathrm{~Pa}$. 217, I04 A.2d xI8 (1954) (1800 square feet for a two-story house, with sliding scale of regulations for other districts). There are also many cases invalidating minimum height restrictions. See generally the discussion in C. A. and A. H. Ratakopf, The Law of Zoning and Planning 456-463 (2d ed. 1949), which the authors state in their preface is based upon a memorandum by Ralph W. Crolly, onc of America's distinguished zoning lawyers.

${ }^{84}$ Thompson v. City of Carrollton, 2 II S.W.2d 970 ('Tex. Civ. App. 1948) (900 square feet-referring to promoting "the beauty of a fashionable residence neighborhood"); Flower Hill Building Corp. v. Village of Flower Hill, I99 Misc. 344, roo N.Y.S.2d 903 (Sup. C. 1950) (I800 square feet); Lionshead Lake v. Wayne Township, 8 N.J. Super. 468, 73 A.2d 287 (Super. Ct. I950), reversed, 9 N.J. Super. 83, 74 A.2d 609 (App. Div. 1950), and 13 N.J. Super. 490, 80 A.2d 650 (Super. Ct. 1951), reversed, ro N.J I65, 89 A.2d 693 (1952), appeal dismissed for want of a substantial federal question, 344 U.S. 919 (1953) (768 square feet for a one-story house, applying generally in an area of about 25 square miles); De Mars v. Zoning Commission of Town of Bolton, 19 Conn. Sup. 24, tog A.2d 876 (1954) (requirements varying with the number of stories). See also Kinsey v. City of Riome, 84 Ga. App. 67x, 67 S.E.2d 206 (I95I); Commonwealth v. MeLaughlin, I68 Pa. Super. 442, 78 A.2d 880 (Super. Ct. I95I).

${ }^{86}$ For more extended discussion, see Haar, Zoning for Minimum Standards: The Wayne Tounship Case, $66 \mathrm{H}_{\mathrm{ARv}}$. L. Rev. I05I (1953); Nolan and Horack, How Small a House?-Zoning for Minimum Space Requirements, 67 HaRv. L. Rev. 967 (1954); Haar, Wayne Township: Zoning for Whom?-In Brief Reply, 67 Harv. L. Rev. 986 (1954); Zoning and Planning Notes, The American City, Feb. 195x, p. 129, id., Oct. 195I, p. 130; id., Nov. 195I, p. 13I; Crolly and Norton, Public Health and Minimum House Size, 72 Regional Plan Associntion Zoning Bull. 1 (r954). 
cause of a feeling that small huuses are necessarily less attractive--which is very close to the same thing. No doubt there are many people who do have such feelingsand no doubt they would like to have the use of governmental powers in order to achieve this end. In other words, such regulations are partly snob zoning, and partly a rather extreme example of aesthetic zoning, heavily interrelated with snob attitudes.

The second argument for ninimum-building-size regulations is concerned with the municipal tax base, and biings out even more sharply (if possible) the basic motive of economic segregation, by spelling out another alleged advantage thereof. According to this argument, a community is entitled to require that all housing built therein shall pay enough ieal estate taxes to cover, or at least to make a substantial contribution towards cuvering, the cost of educational and other services required by its occupants. Rea. estate taxes are generally based on a percentage of assessed value. This argument is then that the cost of housing must be forced up in a district or community-thus promoting economic segregation-in order to force up real estate tax payments. Those who cannot afford bigger houses, and higher taxes, are excluded. This is of ccurse also a direct statement of regressive tax policy.

If regulations such as these are widespread and successful, the implications for the future are clear enough. The great mass of the lower-income groups will continue to live in the existing slum housing, since there would be practically no place left where any substantial amount of new low-cost housing could be built on vacant land. Moreover, the cost of providing for the education and the health of the next generation would be thrown more upon the already heavily over-burdened big cities, which are already increasingly unable to provide adequate services for their inhabitants. One may be permitted to 'loubt whether, all in all, this is a very effective way to promote public health.

A recognition that local zoni.1g requirements on minimum building size arise in fact from considerations other than local concern over public health, is thus but minimum realism. It is apparent that the predominant motives are quite different, and the results will in fact probably be likewise. However, to recognize this is not to say that the size of interior living space has no relation to public health; obviously such a relationship may exist, particularly as a result of the emotional strains resulting when overcrowding actually exists. The problem is to develop criteria to distinguish the real public health regulations from the phony ones. While this is no easy task, a few guideposts are upparent at once. First, it can hardly be seriously argued that such regulations are directed at overcrowing if they do not also include any accompanying control over occupancy. ${ }^{86}$ The same is true if (as frequently) different standards are set for one- and two-story houses. ${ }^{87}$. It is equally true if

\footnotetext{
${ }^{80}$ Significantly, there is no indication in the opinions that the cases listed in footnotes 83 and 84 stupra included any occupancy controls. In the recent Medinger opinion (stipra note 83), the Pennsylvania court stressed these implications of this omission.

${ }^{87}$ Such a distinction was made in Wayne Township (supra note 84 ) (768 square feet for a one-story house, rooo square feet for a two-story house with an attached garage, and I200 square feet for
} 
there is a sliding scale of requirements for different districts, ${ }^{88}$ with larger houses required in the more expensive lower-density districts, where in fact families tend to be smaller. It is also true if buildings of the required minimum size would conform to public health standards for 2 - or 3 -person families, or more. ${ }^{80}$ To regard these merely as ineffectual attempts to regulate overcrowding-as, in effect, legislative ineptitude over and above the call of duty-is to miss the point. The point is that these regulations were concerned with something else, quite specific and quite recognizable; and the public health argument was merely an ill-fitting after-thought.

However, if municipal officials are really determined to use this device for economic segregation, it would not be hard to dress an ordinance up to meet all the tests stated above. The question on local minimum-building-size regulations thus has to be faced squarely. So long as such regulations are in effect on a local basis, both their intent and their effect is likely to be to promote economic segregation. However, if the same controls are in effect on a state-wide or other large-area basis, it may be assumed that they will be adjusted to realistic possibilities in relation to housing needs. ${ }^{90}$

3. Indirect Effects of Other Zoning Regulations. If governmental support for residential segregation by income groups is to be taken seriously, it must be recognized that the problem is not so simple as merely to invalidate those zoning regulations whose sole raison d'être is to promote economic segregation. Several traditional zoning devices, which are primarily concerned with other matters, may nevertheless play an important role along the same lines. The clearest examples are found in the two primary types of residential zoning districts-building-type regulations and density regulations.

As for building-type zoning districts, the restriction of most low-density areas and of most vacant land to single-family detached residences-or sometimes to singleand two-family residences, or to the same plus four-family residences, or some other

a two-story house without an attached garage) and apparently in Medinger (stipra note 83 ) as well. These distinctions in Wayne Tounship, particularly between two-story houses with and without an attached garage, make clear that ordinance's primary concern with how houses looked.

${ }^{88}$ The Medinger opinion brought this point out. However, the two dissenting judges in the New Jersey Supreme Court in Wayne Tounship (where a single set of regulations applied uniformly in an area of about 25 square miles) argued the contrary-that a sliding-scale would have been better constitutionally.

${ }^{89}$ For example, the requirement in Wayne Township for 768 square feet in a one-story housc-a figure apparently actually selected to fit the standard dimensions of locally available lumber-was a bit larger than the public health standard, for 2-person families (750 square feet) which was invoked in defence of the ordinance. See American Public Healtir Association, Committee on the Hygiene of Housing, Planning the Home for Occupancy 36 (I950). This reduces the public-health argument for that ordinance to the proposition that a locality may exclude housing for two-person families-a clearly preposterous proposition of constitutional law.

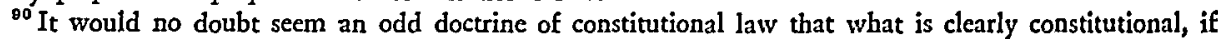
done by the state, is unconstitutional if done locally. Yet the distinctions on policy stated in the text are quite apparent, and there is no reason why courts should be the only agencies of government which do not know what is going on. While it has obvious disadvantages, the distinction between a law's intent and direct effect, and its indirect effect, is widely used in other fields of law (including cminent domain for public housing and urban redevelopment), and may be applicable here. 
similar combination-is often thought of as a density regulation. However, as noted above, apartments are now frequently developed at the same or lower density; and in fact in single-family districts, the real density regulation is not this restriction to single-family houses, but is rather the lot-size, lot-width, and/or side-yard regulations. Be that as it may, such single-family regulations are of course generally accepted as an integral part of modern zoning. However, the most economical way to build good inexpensive housing is probably either in row housing or in taller apartment buildings-partly because of savings on the extra cost of outer walls all around (and also of subsequent heating bills), and sometimes also because of savings in the costs of land and utilities. The effect of such widespread use of single-family zoning restrictions is thus either to raise the cost of moderate-priced shelter, or to lower the other amenities in order to neutralize these increased costs.

The usual highly emotional basis for such zoning arises from the traditional American preference for single-family homes and a large front yard, primarily as symbols of middle-class status. However, here the aesthetic motive is also involved, partly because of the feeling that owner-occupied housing tends to be maintained better.

Genuine density restrictions in residential areas are, as indicated on pages 332 and 345 supra, based upon many of the primary factors in zoning-protection of residential areas against the noise and bustle resulting from congestion, against heavy vehicular traffic and the resulting dangers to safety, against overcrowding of community facilities, and against inadequate amounts of light, air, and open space. Nevertheless, a realistic view of such zoning restrictions must recognize that indirectly they may add to the cost of providing housing, because of the increased cost of land, and especially of frontage and so of utilities. On the other hand, the case against congestion is so compelling on all these grounds that density restrictions are universally agreed to be essential.

The constitutional problem on economic segregation is acute only in the case of extremely low-density regulations, particularly acreage zoning restrictions. ${ }^{91}$ In some cases such restrictions represent an attempt to preserve a quiet and attractive semirural atmosphere, with little noise or bustle and practically no vehicular traffic, and with plenty of room for outdoor play. In such cases it is difficult to draw an arbitrary line at an acre, or anywhere else, to indicate what are the lowest-density regulations

${ }^{9 x}$ Such regulations have been upheld in several recent decisions. Simon v. Needham, 3 II Mass. 560,42 N.E.2d 516 ( $x_{942}$ ) (one acre); Dilliard v. Village of North Hills, $x 95$ Misc. 875, 91 N.Y.S.2d 542 (Sup. Ct. I949), reversed mem., 276 App. Div. 969, 94 N.Y.S.2d 715 (2d Dep't 1950) (2-acre requirement upheld on appeal "as an elastic application of police power"); Gignoux v. Village of Kings Point, I99 Misc. 485, 99 N.Y.S.2d 280 (Sup. Ct. 1950) (one acre); Flora Realty and Investment Co. v. City of Ladue, 362 Mo. 1025, 246 S.W.2d 771 (1952), appeal dismissed for want of a substantial federal question, 344 U.S. 802 ( 1952 ) (3 acres); Franmor Realty Co. v. Village of Old Westbury, 280 App. Div. 945, I16 N.Y.S.2d 68 (2d Dep't 1952), motion for leave to appeal dismissed, 304 N.Y. 843, I09 N.E.2d 714 (1952), and see 28I App. Div. 993, I2x N.Y.S.2d 95 (2d Dep't I953) (2 acres); Fischer v. Township of Bedminster, 2I N.J. Super 8I, 90 A.2d 757 (Super Ct. 1952), aff'd, II N.J. I94, 93 A.2d 378 (1952) (5 acres). In these cases the legal argument has usually focussed upon the question of due process to the developer, not on equal protection for potential residents. 
which can be upheld. In other instances, in estate areas or where land costs are high, there is no question but that acreage zoning regulations are clearly snob restrictions. In still other cases, acreage zoning is not intended to provide for acreage development at all, but to hold back the development of large areas, to prevent the scattering of development. In other words, zoning is here being used as a substitute for subdivision controls regulating the amount and location of development. It is likely to require a very sophisticated community analysis to determine which of these situations is which.

There is a difference, sometimes rather subtle but none the less real, between those communities which want to grow by admitting only "the right kind of people," and others which do not want to grow at all. The latter type of communities simply does not want anybody to move in, because it prefers to maintain its status as a small semi-rural or rural village, untouched by "development." It is difficult to see how any constitutional argument can be brought against such a policy on equal-protection grounds. In some instances, such resistance to development may stand in the way of the best over-all regional pattern-and in such cases the importance of the latter must be balanced against respect for local autonomy and the preservation of small areas with a quiet rural way of life. An example of this attitude, though not a particularly typical one, appears in an important recent New Jersey case on non-conforming uses. In Borough of Rockleigh v. Astral Industries, ${ }^{92}$ the proprietors of a non-conforming factory located in a rural Borough, with 25 homes and ro5 residents in Northern Bergen County, built a water-tower for fire-protection, and also a large water main to bring water to the tower. The Borough authorities objected on the ground that their policy had long opposed bringing a larger water supply into the Borough, since that might encourage more intensive development; and in the resulting lawsuit the court held that the offending water-tower was an unlawful extension of a non-conforming use.

\section{IV}

\section{ConcLusion}

It is a major premise of American democracy that familiarity, at least in the context of economic security and decent living conditions, breeds not contempt but mutual respect. It is a major problem of American democracy that current trends in the development of the physical and social environment are tending to reduce the opportunities for those regular contacts which may result in spontaneous familiarity between different racial, ethnic and economic groups. In an era otherwise characterized by signs of decreasing social fluidity and decreasing racial contacts, such trends have ominous implications for the future of democracy. Now that smalltown society, where friendships and mutual personal respect have a chance to arise naturally between all groups, is no longer a dominant factor in the national scene,

\footnotetext{
${ }^{02} 23$ N.J. Super. 255, 92 A.2d 85 I (Super. Ct. I952), reversed, 29 N.J. Super. I54, 102 A.2d 84 (App. Div. I953), and see I5 N.J. 59I, 106 A.2d 4 I (1954).
} 
the problem is how such relationships will have an opportunity to develop within the forms of social organization which are emerging.

Even if prejudice were regarded as every individual's own business, discrimination-i.e., prejudice translated into action-has such devastating effects upon large segments of the population that it is clearly everybody's business. What is particularly serious is that in this area the machinery of democratic government is itself often used successfully for anti-democratic ends-and that courts, constitutional lawyers, and the leaders of democratic thought and action remain unconcerned. Thus in the last few years, the Supreme Court has repeatedly refused to pass on grave constitutional questions arising in connection with regulation of the physical and social environment. The regulations involved in such cases have included: the exclusion of Negroes from a redevelopment project which had had the benefit of public donation of about 20 per cent of the site, eminent domain to obtain the rest of the site, and partial tax exemption; ${ }^{93}$ a requirement of three acres of land for all homes built in a given district: ${ }^{94}$ a minimum-building-size regulation (varying according to the number of stories and the presence or absence of an attached garage) which applied uniformly throughout an area of some 25 square miles, and which would apparently exclude about 70 per cent of the population from buying permanent new houses in such area; ${ }^{95}$ the exclusion of Negroes from previously built public housing projects; ${ }^{96}$ the exclusion of churches from residential districts; ${ }^{97}$ and the restrictions in the alien land laws on land ownership by Japanese-Americans. ${ }^{\text {8 }}$

This remarkable and widespread lack of interest is due in part to a lack of realization of the significance of a mis-planned environment, and in part to sheer muddleheadedness. The leaders of liberal-democratic thought are all too often so confused with abstractions ("health, safety, morals and welfare," "character of the neighborhood," etc.), so full of respect for local autonomy, and so fearful of judicial

${ }^{03}$ Dorsey v. Stuyvesant Town, 299 N.Y. 512, 87 N.E.2d 54I (1949), cert. denied, 339 U.S. 98I (I950).

¿ Flora Realty and Investment Co. v. City of Ladue, 362 Mo. I025, 246 S.W.2d 77x (x95x), appeal dismissed for want of a substantial federal question, 344 U.S. 802 (I952).

${ }^{05}$ Lionshead Lake v. Wayne Township, 8 N.J. Super. 468, 73 A.2d 287 (Super. Ct. 1950), reversed, 9 N.J. Super. 83, 74 A.2d 609 (App. Div, I950), and I3 N.J. Super. 490, 80 A.2d 650 (Super Ct. 1951), reversed, Io N.J. 165, 89 A.2d 693 (1952), appeal dismissed for want of a substantial federal question, 344 U.S. 919 (1953).

${ }^{\circ 0}$ Banks v. Housing Authority of City and County of San Francisco, 120 Cal. App.2d I, 260 P.2d 668 (1953), cert. denied, 347 U.S. 974 (1954).

${ }^{\circ}$ Corporation of Presiding Bishop of Church of Jesus Christ of Latter-Day Saints v. Porterville, 90 Cal. App.2d 656, 203 P.2d 823 (1949), appeal dismissed for want of a substantial federal question, 338 U.S. 805 (1949).

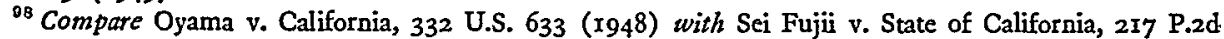
${ }_{4} 8 \mathrm{I}$ (Dist. Ct. App. I950), rehearing denied, 218 P.2d 595 (Dist. Ct. App. r950), aff'd, 38 Cal.2d 718, 242 P.2d 6I7 (r952). See also Monk v. City of Birmingham, 87 F. Supp. 538 (N.D. Ala. I949), aff'd, 185 F.2d 859 (5th Cir. 1950), cert. denied, 34I U.S. 940 (r95I) (racial zoning again invalidatedsee note 49 supra); Standard Oil Co. v. City of Tallahassee, 87 F. Supp. 145 (N.D. Fla. I949), aff'd, I83 F.2d 410 (5th Cir. 1950), cert. denied, 340 U.S. 892 (1950) (compulsory amortization of nonconforming use upheld); McCarthy v. City of Manhattan Beach, 257 P.2d 679 (Cal. App. x953), affd, 41 Cal. 2d 879, 264 P.2d 932 (I953), cert. denied, 348 U.S. 817 (1954) (exclusion of residences from beach-front district). 
review generally, as to be unable to understand the implications of what is going on. It has not been generally realized that in many instances the problems arising in this field of constitutional law are closely akin to those involved in civil liberties law, and call for similar attitudes towards the exercise of governmental power.

Yet, on the whole, the picture is more encouraging than otherwise. There is plenty of evidence of trends which, though often unguided and uncorrelated, are pointing in the right direction. What is needed is a conscious over-all strategy for integration into a more democratic society. Such a strategy would be concerned with analyzing, understanding, and guiding action in wide areas of American lifein fact, everything connected with the development of the physical and social environment, with special emphasis on planning and housing and the relevant fields of law. So far as the special (and basic) problem of integrated residential areas is concerned, tactically it may be wise to concentrate first on the integration of groups whose differences, cultural or otherwise, are not too great; yet it must never be forgotten that the most challenging problems, and the most acute needs for housing and for education and other services, are among the lower-income groups and the racial and ethnic minorities.

In a program such as this, the law may serve both to shed light on the implications of the various problems involved, and actively to help lead the way towards a more democratic America. Herein lines the creative task of the planning lawyer in a democracy. 